\title{
PENGARUH KONSUMSI DAUN KACANG PANJANG TERHADAP PENINGKATAN KADAR HEMOGLOBIN PADA IBU HAMIL TM II DENGAN ANEMIA DI WILAYAH KERJA PUSKESMAS POLANHARJO KABUPATEN KLATEN
}

\author{
Dewi Andang Prastika, Onny Setiani, Sri Sumarni \\ Kementerian Kesehatan Politeknik Kesehatan Surakarta Jurusan Kebidanan \\ Program Magister Kesehatan Lingkungan UNDIP \\ Kementerian Kesehatan Politeknik Kesehatan Semarang Jurusan Kebidanan
}

\begin{abstract}
Long Bean Leaves, Haemoglobin, Pregnancy Second Trimester. Anemia in pregnancy is called the 'potencial danger of mother and child' because anemia is a serious problem and need attention from all parties involved in maternal and child health services. WHO reported that the prevalence of anemia in pregnancy in the world amounted to 55\% and tended to increase with increasing gestational age. To determine the effect of bean leaf consumption to increased hemoglobin levels of second trimesterpregnant women with anemia in Puskesmas Polanharjo working area. This research was Quasy experiment with a pretest posttest control group design. This research used a treatment group is the group of second trimester-pregnant women with anemia has given long bean leaves consumption as many as 15 respondents and the control group is the group of pregnant women with anemia second trimester without additional Fe tablet intake as many as 15 respondents. There is a difference between the average of hemoglobin levels before the intervention group consumed long beans leaves with an average of hemoglobin levels in the intervention group after consuming long beans leaves. By eating 350 grams of long beans leaves for one month (28 days) may help prevent anemia in pregnant women.
\end{abstract}

Keywords : Long Bean Leaves, Haemoglobin, Pregnancy Second Trimester

Abstrak: Daun Kacang Panjang, Haemoglobin, Kehamilan Trimester Kedua. Anemia pada kehamilan disebut 'bahaya potensi ibu dan anak' karena anemia adalah masalah serius dan perlu perhatian dari semua pihak yang terlibat dalam pelayanan kesehatan ibu dan anak. WHO melaporkan bahwa prevalensi anemia pada kehamilan di dunia sebesar $55 \%$ dan cenderung meningkat dengan bertambahnya usia kehamilan. Untuk mengetahui pengaruh konsumsi daun kacang untuk peningkatan kadar hemoglobin trimester hamil wanita kedua dengan anemia di wilayah kerja Puskesmas Polanharjo. Penelitian ini adalah penelitian Quasy dengan desain kelompok kontrol posttest pretest. Penelitian ini menggunakan kelompok perlakuan adalah kelompok wanita trimester hamil kedua dengan anemia telah memberikan kacang panjang daun konsumsi sebanyak 15 responden dan kelompok kontrol adalah kelompok ibu hamil dengan anemia trimester kedua tanpa tambahan asupan tablet $\mathrm{Fe}$ sebanyak 15 responden. Ada perbedaan antara rata-rata kadar hemoglobin sebelum kelompok intervensi dikonsumsi kacang panjang daun dengan rata-rata kadar hemoglobin pada kelompok intervensi setelah mengkonsumsi daun kacang panjang. Dengan makan 350 
gram daun kacang panjang selama satu bulan (28 hari) dapat membantu mencegah anemia pada wanita hamil.

Kata Kunci: Daun Kacang Panjang, Haemoglobin, Kehamilan Trimester Kedua

\section{PENDAHULUAN}

Anemia pada kehamilan disebut dengan 'Potencial danger of mother and child' (potensial membahayakan ibu dan anak), hal itu dikarenakan anemia merupakan masalah yang serius dan sangat memerlukan perhatian yang serius dari semua pihak yang terkait dalam pelayanan kesehatan ibu dan anak ${ }^{1}$. WHO melaporkan bahwa prevalensi anemia pada kehamilan di dunia adalah sebesar 55\% dan cenderung meningkat sesuai dengan bertambahnya usia kehamilan. Berdasarkan survey kejadian di Indonesia, prevalensi anemia ibu hamil mencapai 70 $\%$, dan di Jawa Tengah mencapai $80 \%{ }^{1}$.

Kriteria anemia pada kehamilan menurut organisasi kesehatan dunia (WHO) adalah $\mathrm{Hb}$ kurang dari $11 \mathrm{gr} / \mathrm{dl}$. Sedikit berbeda dengan WHO, The centers for Disease Control and Prevention (CDC) menyebutkan kriteria anemia adalah $\mathrm{Hb}$ kurang dari $11 \mathrm{gr} / \mathrm{dl}$ untuk trimester I dan III, serta $\mathrm{Hb}$ kurang dari 10,5 gr/dl untuk trimester II. Penyebab anemia pada kehamilan paling sering adalah karena defisiensi zat besi dibandingkan dengan defisiensi zat gizi lain. Anemia defisiensi besi dapat terjadi karena kurangnya asupan zat besi dan protein dari makanan, adanya gangguan absorbsi di usus, perdarahan akut maupun kronis, dan meningkatnya kebutuhan zat besi.

Di Indonesia, Departemen Kesehatan menyarankan pemberian tablet besi pada semua wanita hamil sekitar 60 mg perhari selama 90 hari $^{3}$. Ibu hamil diharapkan dapat mengkonsumsi lebih dari 90 tablet selama kehamilan. Akan tetapi, pada kenyataannya, persentase ibu yang melaporkan minum tablet $\mathrm{Fe}$ berdasarkan jumlah hari minum di Indonesia yaitu, minum selama 30 hari hanya 36,3 persen, yang minum 31-59 hari hanya 2,8 persen, minum 60-89 hari berjumlah 8,3 persen dan ibu hamil yang minum tablet Fe selama 90 hari sebanyak 18 persen $^{4}$. Tetapi suplementasi besi folat belum dapat menurunkan prevalensi anemia ibu hamil secara signifikan.

Strategi lain untuk menurunkan angka kejadian anemia khususnya pada ibu hamil adalah dengan memberikan asupan nutrisi yang kaya akan zat besi. Telah banyak dikenal oleh masyarakat bahwa sayuran hijau sangat kaya akan zat besi, kebiasaan masyarakat awam akan mengkonsumsi bayam dan kangkung dalam usaha untuk mencukupi kebutuhan zat besi, namun tanpa disadari bahwa penanaman bayam dan kangkung kini telah banyak ditanam pada tempat-tempat yang terpapar banyak polutan sehingga kandungan nutrisi yang seharusnya bermanfaat beralih menjadi hal yang harus diwaspadai. Salah satu contoh asupan sayuran lain yang sering dikonsumsi dan juga sangat kaya akan zat besi adalah daun kacang panjang. Dilaporkan hasil sebuah penelitian dari Rahmat (2009) dalam SEAFAST 2012, menyatakan bahwa dalam 100 gr daun kacang panjang memiliki 6,2 $\mathrm{mg}$ zat besi dengan tingkat kelarutan besi dalam tubuh cukup tinggi yaitu sekitar 17,4 \%. Daun kacang panjang yang tumbuh menjalar ke atas dan jarang dilakukan penyemprotan dengan 
pestisida akan meminimalisir kemungkinan daun tercemar pestisida secara langsung ${ }^{3}$. Dengan demikian diharapkan daun kacang panjang mampu menjadi alternative asupan nutrisi penambah darah yang ramah terhadap ibu dan janinnya.

\section{METODE PENELITIAN}

Quasy experiment dengan rancangan pretest postest control group design. Dalam penelitian ini digunakan satu kelompok perlakuan yaitu kelompok ibu hamil trimester II dengan anemia yang diberi konsumsi daun kacang panjang dan kelompok kontrol yaitu kelompok ibu hamil trimester II dengan anemia yang tidak diberikan suplementasi tablet fe.

Populasi studi pada penelitian ini adalahsemua ibu hamil TM II yang berada di wilayah kerja Puskesmas Polanharjo Kabupaten Klaten responden penelitian ini seluruhnya berjumlah 30 responden. Dimana 15 responden adalah kelompok kontrol dan 15 responden kelompok intervensi.

Variabel penelitian ini terdiri dari konsumsi daun kacang panjang, kadar hemoglobin, anemia, asupan makanan. Pengolahan data dan analisis data menggunakan computer prograf PASW 18.Analisis terdiri dari analisis univariat dan bivariat.

\section{HASIL PENELITIAN}

\begin{tabular}{cccc}
\multicolumn{2}{c}{ Karakteristik } & \multicolumn{2}{c}{ responden } \\
$\begin{array}{ccc}\text { ditunjukkan dalam tabel 1 } \\
\text { Karakteristik }\end{array}$ & Kelompok & $\begin{array}{c}\text { Frekuensi } \\
\text { (orang) }\end{array}$ & $\begin{array}{c}\text { Prosentase } \\
(\%)\end{array}$ \\
\hline Umur & $<20$ tahun & 0 & 0,00 \\
& $20-35$ & 15 & 100,00 \\
& tahun & 0 & 0,00 \\
Tingkat & $>35$ tahun & & \\
pendidikan & SD & 0 & 0,00 \\
& SMP & 3 & 20,00 \\
& SMA & 10 & 66,67 \\
& PT & 2 & 13,33 \\
& Jumlah & 15 & 100 \\
\hline
\end{tabular}

Pengumpulan data umur responden dilakukan pada awal screening responden. Dari hasil penelitian, menunjukkan karakteristik responden berdasarkan umur secara keseluruhan berusia antara 20-35 tahun. Usia minimal responden adalah 22 tahun, sedangkan maksimal usia responden adalah 32 tahun. Rata-rata usia responden

Dari pengumpulan data yang telah dilakukan, karakteristik responden berdasarkan tingkat pendidikan responden menunjukkan bahwa 3 orang responden memiliki tingkat pendidikan SMP, kemudian 10 orang responden memiliki tingkat pendidikan SMA, sedangkan 2 responden memiliki tingkat pendidikan Perguruan Tinggi. Hal ini dapat disimpulkan bahwa tingkat pendidikan responden cukup baik dilihat dari $66,67 \%$ responden telah menyelesaikan pendidikan sampai tingat menengah atas dan tidak ada responden yang hanya menyelesaikan pendidikan sampai tingkat dasar. Dari pengumpulan data yang telah dilakukan, karakteristik responden berdasarkan tingkat pendidikan responden menunjukkan bahwa 3 orang responden memiliki tingkat pendidikan SMP, kemudian 10 orang responden memiliki tingkat pendidikan SMA, sedangkan 2 responden memiliki tingkat pendidikan Perguruan Tinggi. Hal ini dapat disimpulkan bahwa tingkat pendidikan responden cukup baik dilihat dari 66,67 \% responden telah menyelesaikan pendidikan sampai tingat menengah atas dan tidak ada responden yang hanya menyelesaikan pendidikan sampai tingkat dasar.

\section{PEMBAHASAN}

Dalam 100 gram daun kacang panjang terdapat $6,2 \mathrm{mg}$ besi, $29 \mathrm{mg}$ 
vitamin C, 4,1 gr protein, dan $88,10 \pm 0,28$ $\%$ air. Besi diet yang berasal dari daun kacang panjang diserap di dalam lambung (pH 1,5) sebanyak $17,4 \%$, sedangkan dalam duodenum $(\mathrm{pH}$ 7,5) terserap sebesar $15,5 \pm 0,29 \%$.

Berdasarkan data kandungan gizi pada daun kacang panjang di atas, dapat dicermati bahwa mengkonsumsi daun kacang panjang sangat baik untuk mencegah atau memperbaiki kondisi anemia pada ibu hamil hal ini dapat dibuktikan dengan tingginya kandungan zat besi yang terkandung didalamnya yaitu sebesar 6,2 mg per 100 gram daun kacang panjang segar dengan tingkat penyerapan sebesar 17,4\%. Selain itu, didukung pula oleh kandungan asam askorbat (vitamin C) yang terkandung didalamnya sebesar $29 \mathrm{mg}$ per 100 gram daun kacang panjang dimana sifat dari asam askorbat ini adalah untuk membantu penyerapan zat besi dalam tubuh.

Proses penyerapan besi dalam duodenum terdiri dari 3 fase yaitu fase luminal, fase mucosal, dan fase sistemik atau korporeal. Pada fase luminal ikatan besi dari bahan makanan dilepaskan atau dirubah menjadi bentuk terlarut dan terionisasi. Kemudian besi dalam bentuk feri $\left(\mathrm{Fe}^{3+}\right)$ direduksi menjadi bentuk fero $\left(\mathrm{Fe}^{2+}\right)$ sehingga siap diserap usus. Dalam proses ini getah lambung memegang peranan penting. Absorbs paling baik terjadi pada duodenum dan jejenum proksimal. Hal ini dihubungkan dengan jumlah reseptor pada permukaan usus dan pH usus. Di dalam usus, besi akan dibedakan menjadi besi heme, dan non heme. Kedua jenis besi ini memiliki sifat yang sangat berbeda. Besi heme diserap secara langsung, tidak dipengaruhi oleh bahan penghambat atau pemacu dan presentase absorbsinya besar yaitu 4 kali dari besi non heme. Sedangkan absorbs besi non heme sangat dipengaruhi oleh zat pengikat (ligand) yang dapat menghambat ataupun memacu absorbsi. Senyawa besi heme diserap secara utuh dan setelah berada dalam epitel usus akan dilepaskan dari rantai porfirin oleh enzim haemoxygenase, kemudian ditransfer ke dalam plasma atau disimpan dalam ferritin. Presentase penyerapan besi sangat tinggi yaitu $10-25 \%$. Penyerapan besi non heme sangat dipengaruhi oleh adanya zat yang mempertahankan besi tetap dalam keadaan terlarut yaitu vitamin c (asam askorbat). Bahan ini disebut dengan zat pemacu atau promoter atau enhancer. Pada daun kacang panjang terdapat vitamin c (asam askorbat) yang merupakan bahan pemacu absorbs besi yang sangat kuat yang berfungsi sebagai reduktor yang dapat mengubah feri menjadi fero, mempertahankan $\mathrm{pH}$ usus tetap rendah sehingga mencegah presipitasi besi dan bersifat sebagai monomeric chelator yang membentuk iron-ascorbate chelate yang lebih mudah diserap oleh tubuh. Setelah itu, besi diserap secara aktif melalui reseptor. Jika dosis terlalu besar besi akan masuk secara difusi pasif. Dalam sel enterosit besi akan diikat oleh suatu karier protein spesifik dan ditransfer melalui sel ke kapiler atau disimpan dalam bentuk ferritin dalam enterosit kemudian dibuang bersamaan dengan deskuamasi epitel usus. Pada fase sistemik, besi yang masuk ke plasma akan diikat oleh apotransferin menjadi transferrin dan diedarkan ke seluruh tubuh, terutama ke sel eritroblast dalam sumsum tulang. Semua sel mempunyai reseptor transferrin pada permukaannya. Transferrin ditangkap oleh reseptor ini dan kemudian melalui proses pinositosis (endositosis) masuk dalam vesikel 
(endosome) dalam sel. Akibat penurunan $\mathrm{pH}$, besi, transferrin, dan reseptor akan terlepas dari ikatan. Besi akan dipakai oleh sel sedangkan reseptor dan transferrin dikeluarkan untuk dipakai ulang. Pada keadaan ini, tubuh akan tercukupi penyediaan besinya sehingga metabolisme besi berjalan lancar.

Pemberian suplemen daun kacang panjang dan nutrisi yang baik selama 4 minggu pada ibu hamil TM II dengan anemiadengan kandungan Fe setara kadar zat besi yang tinggi mencapai $23,45 \mathrm{mg}$, vitamin C sebanyak $101,5 \mathrm{mg}$, dan protein sebanyak 14,35 gr dapat meningkatkan kadar $\mathrm{Hb}$ pada ibu hamil rata-rata 1,72 gr/dl per minggunya hal ini menunjukkan bahwa peningkatan kadar hemoglobin setelah pemberian konsumsi daun kacang panjang berada di atas harapan, yaitu 0,3 gr/ dl/ minggu ${ }^{5}$. Rata-rata kadar hemoglobin tertinggi terjadi pada minggu keempat yaitu sebesar 15,88 gr/dl sedangkan kenaikan rata-rata kadar hemoglobin tertinggi terjadi pada minggu kedua yaitu mencapai 42,84\%. Kenaikan rata-rata kadar hemoglobin pada minggu pertama mencapai $12,87 \mathrm{~g} / \mathrm{dl}$, mg ke 2 14,33, kenaikan rata-rata kadar hemoglobin minggu ketiga mencapai $14,90 \mathrm{gr} / \mathrm{dl}$, dan kenaikan rata-rata kadar hemoglobin pada minggu keempat mencapai 15,88 gr/dl, sedangkan kelompok control bervariasi untuk kadar hemoglobin selama 4 minggu, namun hasil penelitian menunjukkan bahwa pada kelompok kontrol kadar $\mathrm{Hb}$ tergantung dari kualitas asupan makanan masing masing.

\section{KESIMPULAN DAN SARAN}

Pemberian suplemen berupa daun kacang panjang terbukti secara signifikan meningkatkan kadar Hb sampai dengan 76 $\%$. Hasil penelitian yang menunjukkan bahwa pemberian suplemen daun kacang panjang terbukti secara signifikan dapat meningkatkan kadar $\mathrm{Hb}$, dapat diterapkan secara praktis dan aman, karena selain mudah dan murah juga daun kacang panjang merupakan suplemen alami yang baik untuk meningkatkan kadar $\mathrm{Hb}$. Kadar Vitamin $\mathrm{C}$ yang tinggi pada daun kacang panjang juga sangat baik untuk meningkatkan penyerapan $\mathrm{Fe}$ dalam tubuh, meningkatkan kadar sel darah merah dan $\mathrm{Hb}$ pada ibu hamil trimester II.

\section{DAFTAR RUJUKAN}

Mansjoer, A. 2001. Kapita Selekta Kedokteran. Jilid 1. Edisi 3. Jakarta: Media Aesculapius: 253: 255: $550-1$

Departemen Kesehatan R.I. Ditjen Kesehatan Masyarakat.: Pedoman Pemberian Besi bagi Petugas. Jakarta: Departemen Kesehatan, I5; 2000.

Riset Kesehatan Dasar. 2010. Jakarta : Badan Penelitian dan Pengembangan Kesehatan

SEAFAST center.2012. senyawa fenolik pada Sayuran Indigenous.

Arisman MB. 2004. Gizi dalam Daur Kehidupan : Buku Ajar Ilmu Gizi. Jakarta : EGC. hal : 2-13,144-7. 